\title{
Distribution of AdeABC Efflux System Genes in Acinetobacter baumannii Isolated from Blood Cultures of Hospitalized Patients and Their Relationship with Carbapenem and Aminoglycoside Resistance
}

\author{
Kan Kültürlerinden Izole Edilen Acinetobacter baumannii Izolatlarında AdeABC Efluks Pompası \\ Genlerinin Dağııımı ve Karbapenem-Aminoglikozit Direnci ile Ilişsisinin Araştııılması
}

\author{
(1) Hamza ARi ${ }^{1}$, (1) Okan AYDOĞAN ${ }^{1}$, (1) Mehmet DEMiRCi ${ }^{2}$, (1) Fatma KÖKSAL ÇAKIRLAR ${ }^{1}$ \\ 1 istanbul University-Cerrahpaşa, Cerrahpaşa Faculty of Medicine, Department of Medical Microbiology, istanbul, Turkey \\ 2 Beykent University Faculty of Medicine, Department of Medical Microbiology, Istanbul, Turkey
}

\section{Abstract}

Introduction: The increasing emergence of multidrug-resistant (MDR) Acinetobacter infections has become a significant challenge for physicians and clinical microbiologists owing to the difficulties arising during therapy. The major efflux mechanism associated with MDR in A. baumannii is the chromosomally encoded tripartite efflux pump, AdeABC, which has been reported worldwide. AdeABC belongs to the resistance-nodulation-division efflux pump family and has a three-component structure: AdeB forms the transmembrane component, AdeA forms the inner membrane fusion protein, and $\mathrm{AdeC}$ forms the outer membrane protein. AdeABC is chromosomally encoded and is regulated by a two-component system containing a sensor kinase (AdeS) and its associated response regulator (AdeR). Point mutations in these components are associated with the overexpression of AdeABC, thereby leading to multiple drug resistance. The purpose of this study was to investigate the distribution of the AdeABC efflux pump genes and their relationship with carbapenem and multiple drug resistance in A. baumannii strains isolated from the blood cultures of hospitalized patients.

Materials and Methods: A total of 97 A. baumannii strains that were isolated from the blood cultures of hospitalized patients in different departments, were included in the study. The Phoenix Automated System was used to identify and determine antibiotic susceptibility patterns. The susceptibility of the study strains to carbapenems, ciprofloxacin, trimethoprim-sulfamethoxazole, amikacin, gentamicin, and netilmicin were determined according to European Committee on Antimicrobial Susceptibility Testing (EUCAST) criteria. AdeRS mutations and adeB gene expression of drug efflux genes were analyzed by sequencing and qPCR, respectively. The $16 \mathrm{~S}$ rRNA gene was used as a housekeeping gene, and the $A$. baumannii ATCC 19606 standard strain was also used to normalize the expression results of adeB gene.

Results: Of the 97 isolates, 61 were found to be carbapenem resistant. The resistance rates of carbapenem-resistant $A$. baumannii (CRAB) isolates were found to be $100 \%$ for ceftazidime; $96.7 \%$ for cefepime, piperacillin-azobactam, ciprofloxacin, and trimethoprim-sulfamethoxazole; $86.8 \%$ for amikacin; and 75.4\% for gentamicin and netilmicin. The significant overexpression (3.45-52.18 fold) of adeB was observed in 49 CRAB isolates, whereas less increased levels were observed in only 12 CRAB isolates (0.23-0.54 fold) and non-CRAB isolates (0.109-0.783 fold). In total, 80.3\% of the CRAB isolates were positive for the adeRS genes. The p.Val120lle change in the AdeR aminoacid sequence was determined in $42.8 \%$ of the ade $B$-overexpressing CRAB isolates. The p.His158Leu and p.Pro116Ser changes were found in 36.7\% of these isolates. None of the non-CRAB isolates had p.Val120lle, p.His158Leu, and p.Pro116Ser changes. In the AdeS aminoacid sequence, p.Gly293Ser, p.Leu105Phe, and His227Asp changes were most commonly observed in adeB-overexpressing CRAB isolates, whereas pGly293Ser change was detected in only 8\% of the non-CRAB isolates. Conclusion: These data showed that AdeABC efflux pump overexpression (both adeB expression and AdeRS mutation) was higher than expected in our A. baumannii isolates. They were significantly associated with the AdeABC efflux system and both CRAB and MDR isolates. The overexpression

Cite this article as: Ari H, Aydoğan 0, Demirci M, Köksal Çakırlar F. Distribution of AdeABC Efflux System Genes in Acinetobacter baumannii Isolated from Blood Cultures of Hospitalized Patients and Their Relationship with Carbapenem and Aminoglycoside Resistance. Mediterr J Infect Microb Antimicrob. $2019 ; 8: 32$.

Address for Correspondence/Yazışma Adresi: Okan Aydoğan, İstanbul University-Cerrahpaşa, Cerrahpaşa

Faculty of Medicine, Department of Medical Microbiology, Istanbul, Turkey

E-mail: okanaydogan4@gmail.com 0RCID ID: orcid.org/0000-0001-7275-8724

Received/Geliş Tarihi: 01.06.2019 Accepted/Kabul Tarihi: 06.11.2019

-Copyright 2019 by the Infectious Diseases and Clinical Microbiology Specialty Society of Turkey

Mediterranean Journal of Infection, Microbes and Antimicrobials published by Galenos Yayınevi.
Presented in: This study was presented at the $7^{\text {th }}$ Asia Pacific STD and Infectious Diseases Congress, October 2017, Osaka, Japan.

Published: 8 November 2019 
of $a d e B$ and aminoacid changes in the AdeRS regions led to an increase resistance to different antibiotics; therefore, $A$. baumannii strains should be monitored to ensure the correct treatment, especially in nosocomial MDR.

Keywords: Proteomics, efflux system genes, aminoglycoside resistance, blood stream infections, carbapenem resistance

\section{Öz}

Giriş: Çok ilaca dirençli Acinetobacter enfeksiyonlarının artması, hekimler ve klinik mikrobiyologlar için tedavide büyük zorluklar oluşturmaktadır. AdeABC, kromozomal olarak kodlanan ve son zamanlarda tüm dünyadan bildirilen çoklu ilaç direnci ile ilişkili efflux mekanizmasıdır. AdeABC üç bileşenli bir yapıya sahiptir. AdeB, transmembran bileşenini, AdeA, iç membran füzyon proteinini ve AdeC, dış membran proteinini oluşturur. AdeABC bir sensör kinaz (AdeS) ve bir regülatör (AdeR) içeren iki bileşenli bir sistem tarafından düzenlenir. Bu bileşenlerde nokta mutasyonları, çoklu ilaç direncine yol açan AdeABC'nin aşırı ekspresyonu ile ilişkilidir. Bu çalışmanın amacı, hastanede yatan hastaların kan kültürlerinden izole edilen $A$. baumannii'de AdeABC efflux pompa genlerinin dağılımını ve bunların karbapenem ve çoklu ilaç direnciyle ilişkilerini araştırmaktır.

Gereç ve Yöntem: Hastanenin farklı bölümlerinde yatan hastaların kan kültürlerinden izole edilen toplam 97 A. baumannii kökeni çalışmaya dahil edildi. Çalışma kökenlerinin antibiyotik duyarlılık paternleri Phoenix Otomatik Sistemi ile belirlendi. Suşların karbapenemler, siprofloksasin, trimetoprim-sülfametoksazol, amikasin, gentamisin ve netilmisine duyarlılıkları "European Committee on Antimicrobial Susceptibility Testing" (EUCAST) kriterlerine göre belirlendi. AdeRS mutasyonları ve adeB gen ekspresyonu dizileme ve qPCR ile analiz edildi. Referans gen olarak 16 s rRNA geni ve A. baumannii ATCC 19606 standart suşu kullanıldı.

Bulgular: Doksan yedi kökenin 61'i karbapenem dirençliydi. Karbapenem dirençli $A$. baumannii (CRAB) izolatlarının direnç oranları seftazidime $\% 100$; sefepime, piperasilin-tazobaktam, siprofloksasin ve trimetoprim-sülfametoksazole \%96,7; amikasine \%86,8; gentamisin ve netilmisine \%75,4 olarak bulundu. Kırk dokuz CRAB izolatında adeB aşırı ekspresyonu (3,45-52,18 kat) gözlendi, ancak sadece 12 CRAB izolatında (0,23-0,54 kat) ve CRAB olmayan izolatlarda (0,109-0,783 kat) daha az artış gözlendi. CRAB izolatlarının \%80,3'ü adeRS genleri için pozitifti. AdeR aminoasit dizisindeki p.Val120lle değişimi, $a d e B$-aşırı eksprese eden CRAB izolatlarının \%42,8'inde belirlendi.

Sonuç: Verilerimiz A. baumannii izolatlarımızda AdeABC efflux pompası aşırı ekspresyonunun beklenenden daha yüksek olduğunu gösterdi. AdeABC efflux sistemi; hem CRAB hem de çoklu ilaç dirençli izolatlar ile anlamlı şekilde ilişkiliydi. AdeRS bölgelerinde adeB ve aminoasit değişikliklerinin aşırı ekspresyonu, farklı antibiyotiklere karşı artan bir direnç ortaya çıkmasına neden olmuştur, bu nedenle özellikle nozokomiyal çoklu ilaç direncinde doğru tedaviyi sağlamak için A. baumannii kökenleri izlenmelidir.

Anahtar Kelimeler: Proteomik, efflux genleri, aminoglikozit direnci, kan dolaşımı enfeksiyonları, karbapenem direnci

\section{Introduction}

Acinetobacter baumannii is a ubiquitous, Gram-negative coccobacillus, which is an important nosocomial pathogen that causes various infections, such as wound infections, bloodstream infections, ventilator-acquired pneumonia, central nervous system infections, and urinary tract infections. In fact, $A$. baumannii is considered as an opportunistic pathogen. The increasing emergence of multidrug-resistant (MDR) Acinetobacterspp. infections has become a significant challenge for physicians and clinical microbiologists due to the difficulties arising during therapy ${ }^{[1-4]}$. The major efflux mechanism associated with MDR in A. baumannii is the chromosomally encoded tripartite efflux pump, AdeABC, which has been reported globally. AdeABC belongs to the resistance-nodulation-division efflux pump family and has a three-component structure: AdeB forms the transmembrane component, AdeA forms the inner membrane fusion protein, and AdeC forms the outer membrane protein. AdeABC is chromosomally encoded and is regulated by a two-component system containing a sensor kinase (AdeS) and its associated response regulator (AdeR). Point mutations in these components are associated with the overexpression of AdeABC, thereby leading to multiple drug resistance. This major efflux mechanism is associated with carbapenems, aminoglycosides, fluoroquinolones, tetracyclines, amphenicols, macrolides, and trimethoprim sulfamethoxazole $\mathrm{e}^{[5-9]}$.

The purpose of this study was to investigate the distribution of the $A d e A B C$ efflux pump genes and their relationship with carbapenems and aminoglycosides susceptibility in A. baumannii strains isolated from the blood cultures of hospitalized patients.

\section{Materials and Methods}

According to the "Ethical Principles for Medical Research Involving Human Subjects" of the principles of the World Medical Association Declaration of Helsinki (amended in October 2013), the İstanbul University-Cerrahpaşa, Cerrahpaşa Faculty of Medicine Ethics Committee of Clinical Research (decision no: 2015/147) granted the approval to this study. The written informed consent was obtained from the study participants.

\section{Sample Collection}

Study strains were the 97 A. baumannii strains that were isolated from the blood cultures of hospitalized patients in different departments (intensive care 49\%, surgery 19.6\%, hematology $9.8 \%$, orthopedics and traumatology $3 \%$, and internal medicine 18\%) of İstanbul University-Cerrahpaşa, Cerrahpaşa Faculty of Medicine Hospital, İstanbul, Turkey. 


\section{Antimicrobial Susceptibility Testing}

The BD Phoenix ${ }^{\text {TM }}$ automated identification and susceptibility pattern-testing system (Becton-Dickinson Company, Franklin Lakes, NJ, USA) was used to identify and determine the antibiotic susceptibility. The concentration gradient-based E-test (bioMérieux, France) strip method was employed to measure the minimum inhibitory concentration (MIC) values in imipenem, meropenem, and colistin in vitro susceptibility tests. The susceptibilities of the strains to carbapenems, ciprofloxacin, trimethoprim-sulfamethoxazole, amikacin, gentamicin, and netilmicin were determined according to the European Committee on Antimicrobial Susceptibility Testing (EUCAST) criteria $^{[10]}$.

\section{ade $B$ Gene Expression}

The ribonucleic acid (RNA) samples were isolated by using the High Pure RNA isolation kit (Roche Diagnostics $\mathrm{GmBH}$, Mannheim, Germany) from A. baumannii strains produced in the Luria Bertani (LB) medium (Sigma-Aldrich, St. Louis, MO, USA) in accordance with the manufacturer's instructions. The obtained RNA samples were stored at $-80{ }^{\circ} \mathrm{C}$ until they were processed by qPCR LightCycler 480 II (Roche Diagnostics $\mathrm{GmBH}$ ). Prior to $q P C R$ runs, the ratios of RNAs at A260/A280 nm were examined on a NanoDrop 2000 spectrophotometer (Thermo Fisher Scientific, Waltham, MA, USA) for the calculation of the quantities and purity values. Complementary DNA (cDNA) synthesis was performed by using the Transcriptor First Strand cDNA Synthesis Kit (Roche Diagnostics $\mathrm{GmBH}$ ) by adhering to the manufacturer's instructions. Each sample weighed $50 \mathrm{ng}$. The 165 rRNA gene was used as a housekeeping gene. The primers were ordered from IDT (Integrated DNA Technologies Inc., Skokie, IL, USA) and were used for qPCR steps for the adeB and $16 S$ rRNA genes. These primers are presented in Table 1.

The qPCR experiments were performed by using the LightCycler 480 SYBR Green I Master kit (Roche Diagnostics $\mathrm{GmBH}$ ) to detect the ade $B$ and $16 S$ rRNA genes in accordance with the manufacturer's instructions. The qPCR protocol consisted of enzyme activation for $10 \mathrm{~min}$ at $95^{\circ} \mathrm{C}$. After 45 cycles, there was an amplification phase of $10 \mathrm{~s}$ at $95^{\circ} \mathrm{C}, 20 \mathrm{~s}$ at $60^{\circ} \mathrm{C}$, and $3 \mathrm{~s}$ at $72{ }^{\circ} \mathrm{C}$, which was followed by $1 \mathrm{~s}$ of denaturation at $95^{\circ} \mathrm{C}, 60$ s at $65^{\circ} \mathrm{C}$, and continuous reading up to $97^{\circ} \mathrm{C}$. The fluorescence data were obtained automatically, and the ade $B$ and $16 S$ rRNA $\mathrm{Cp}$ values were generated for each isolate by using the $\Delta \mathrm{Ct}$ method. The A. baumannii ATCC 19606 standard strain was also used to normalize the ade $B$ gene expression results ${ }^{[11]}$. Each isolate was tested in duplicate samples in two independent experiments.

\section{AdeRS mutations}

Deoxyribonucleic acid (DNA) isolations were performed by using the High Pure PCR Template preparation kit (Roche Diagnostics
$\mathrm{GmBH}$ ) from the $A$. baumannii strains generated in the LB medium in accordance with the manufacturer's instructions. The obtained DNA sample was stored at $-20^{\circ} \mathrm{C}$ until the process of sequencing. DNA sequencing for the detection of mutations in the ade $R$ and adeS genes was performed by using the primers shown in Table 1. Primers were obtained from IDT (Integrated DNA Technologies Inc.). DNA sequencing was performed by using the automated MegaBACE 1000 (Amersham Biosciences, CA, USA) sequencing system in accordance with the manufacturer's instructions. At the end of the process, the chromatogram files obtained for the AdeS and AdeR gene regions were compared with the sequences obtained by downloading them after being converted to the FASTA format (See Supplementary Table 1 for GenBank Accession Numbers-placed after the references).

\section{Results}

Of the 97 isolates, 61 were found to be carbapenem resistant. The MIC values were found to range between $8-12 \mathrm{mg} / \mathrm{ml}$ for imipenem and meropenem.

The resistance rates of carbapenem-resistant $A$. baumannii (CRAB) isolates were found to be $100 \%$ for ciprofloxacin and trimethoprim-sulfamethoxazole, $86.8 \%$ for amikacin, and $75.4 \%$ for gentamicin and netilmicin (Figure 1). The significant overexpression (3.45-52.18 fold) of ade $B$ was observed in the 49 CRAB isolates, whereas only 12 CRAB isolates (0.23-0.54 fold) and non-CRAB isolates (0.109-0.783 fold) had less increased levels (Figures 2, 3). Of the 97 isolates, 42 were resistant to aminoglycosides. The significant overexpression (21.38-51.68 fold) of ade $B$ was displayed in the 34 aminoglycoside-resistant isolates and was found to be positive for the AdeRS gene. Eight aminoglycoside-resistant isolates had low levels (0.23-0.54) of $a d e B$, which were found to be negative for the adeRS gene (Table 2).

Approximately $80.3 \%$ of the CRAB isolates were found to be positive for the adeRS gene, the p.Val120lle change in the AdeR amino acid sequence was determined in the $21(42.8 \%)$ isolates of ade $B$-overexpressing $C R A B$ isolates. In total, 14 of these

Table 1. Oligonucleotide sequences used for the $\operatorname{ade} B, 16 \mathrm{~S}$ rRNA, adeS, and ade $R$ genes

\begin{tabular}{|c|c|c|}
\hline Target & Oligonucleotide sequences & References \\
\hline adeB-F & AACGGACGACCATCTTGAGTATT & Peleg et al. ${ }^{[9]}$ \\
\hline adeB-R & CAGПGПССАПTCACGCAП & Peleg et al. ${ }^{[9]}$ \\
\hline $16 \mathrm{~S}$ rRNA-F & АСTCCTACGGGAGGCAGCAGT & Selasi et al..$^{[11]}$ \\
\hline 16S rRNA-R & TAПACCG CGGCTGCTGGC & Selasi et al..$^{[11]}$ \\
\hline adeR-F & AGCGTATGATGAGTTGAAGCA & Bratu et al..$^{[12]}$ \\
\hline adeR-R & AATCCAGCCTTTTCAATCG & Bratu et al. ${ }^{[12]}$ \\
\hline adeS-F & CGTGGCGTGGGATATAGACT & Bratu et al.. ${ }^{[12]}$ \\
\hline adeS-R & AGGAAAATGCCACAAAATGG & Bratu et al. ${ }^{[12]}$ \\
\hline
\end{tabular}




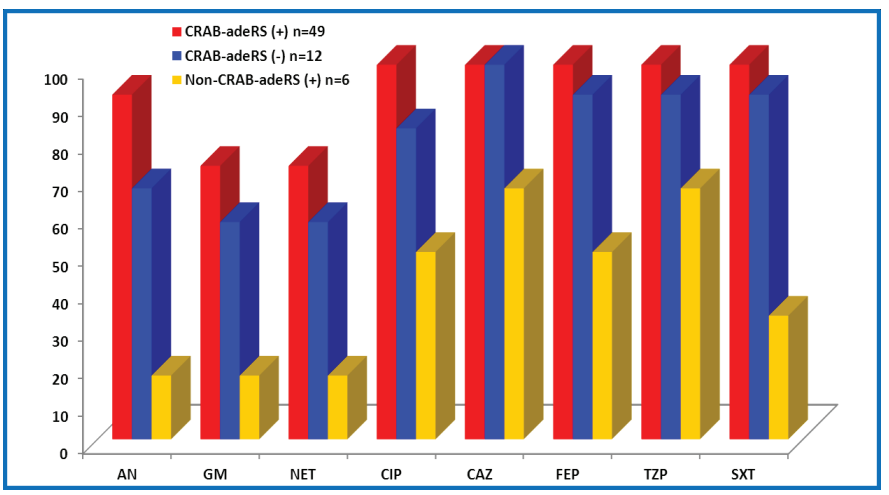

Figure 1. Comparison of antibiotic resistance of carbapenem-resistant $A$. baumannii (CRAB) adeRS+, CRAB adeRS-, and nonCRAB adeRS+

AK: Amikacin, GM: Gentamicin, NET: Netilmicin, CIP: Ciprofloxacin, CAZ: Ceftazidime, FEP: Cefepime, TZP: Piperacillin-tazobactam, SXT: Trimethoprimsulfamethoxazole, CRAB: Carbapenem-resistant $A$. baumannii

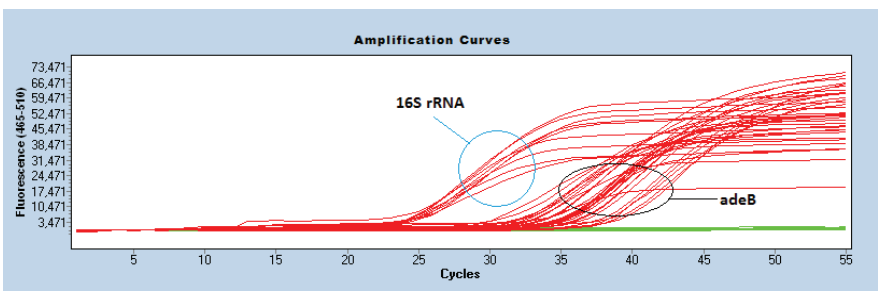

Figure 2. qPCR amplification curves of $a d e B$ and $16 \mathrm{~S}$ rRNA genes in $A$. baumannii isolates

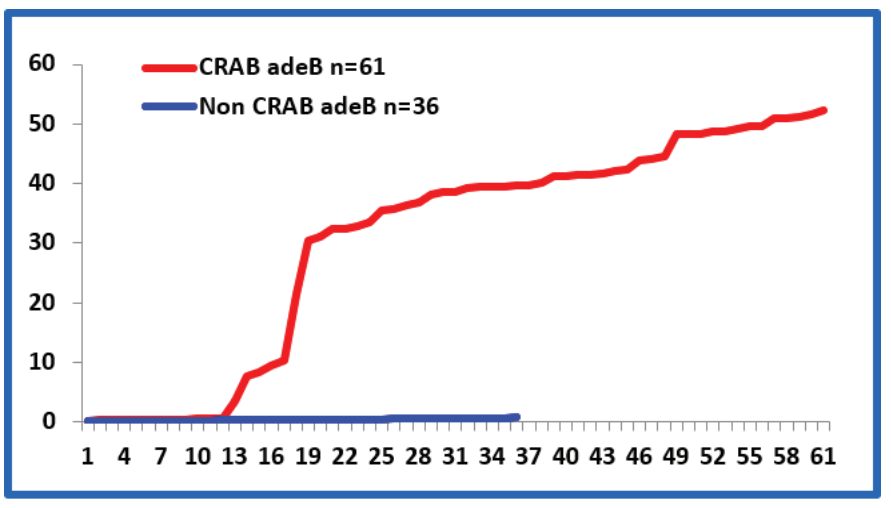

Figure 3. Comparison of $a d e B$ gene expression fold of carbapenemresistant $A$. baumannii (CRAB) and non-CRAB isolates

CRAB: Carbapenem-resistant $A$. baumannii

isolates were aminoglycoside-resistant isolates. The p.His158Leu and p.Pro116Ser changes were observed in $36.7 \%$ of the CRAB isolates. Eight of the aminoglycoside-resistant isolates showed change in p.His158Leu, and 15 of them showed p.Pro116Ser change. None of the non-CRAB isolates and aminoglycosidesusceptible isolates showed p.Val120lle, p.His158Leu, and p.Pro116Ser changes. In the AdeS amino acid sequence, p.Gly293Ser, p.Leu105Phe, and p.His227Asp changes were most commonly observed in the ade $B$-overexpressing CRAB isolates and aminoglycoside-resistant isolates. The p.Gly293Ser change was detected in only $8 \%$ of the non-CRAB isolates (Table 3 ).

\section{Discussion}

The RND family is a multidrug efflux pump and plays a vital role in the antimicrobial resistance of $A$. baumannii. The first characterized RND system in $A$. baumannii samples was the AdeABC efflux pump. The expression is controlled by the twocomponent regulatory system known as adeS and $a d e R^{[12-14]}$. The MDR phenotype against antimicrobials is more expressed than the natural isolates at this pump ${ }^{[13,15]}$.

Aminoglycosides are the antibiotics most affected by the ABC-type pumps ${ }^{[16-18]}$. For this reason, we tried to measure the expression level of ade $B$ gene and investigate the mutation of ade $R$ and adeS genes, the regulatory compartments, and their relationship with carbapenemase production in $A$. baumannii samples isolated from the blood cultures of hospitalized patients. This study found that the ade $B$ gene expression increased 52-fold with p.Val120lle aminoacid change. In addition, there was a 50-fold increase with p.Pro116Ser and p.His158Leu aminoacid changes for the AdeR region. The aminoacid changes of p.Gly293Ser, p.Leu105Phe, and p.His227Asp were observed most frequently in the cases of adeB overexpression for the AdeS region. The most frequent p.Val120lle change was observed in the 97 isolates for the AdeR region, whereas the most frequent p.Gly293Ser change was observed for the AdeS region.

Qiu et al. ${ }^{[19]}$ reported that the $a d e B$ expression of CRAB isolates was 10.4-62.3 times higher than that of non-CRAB isolates. Our study found similar results. The CRAB isolates had at least 3.4552.18 times higher overexpression pattern for the ade $B$ gene. Coyne et al. ${ }^{[20]}$ reported that the ade $B$ overexpressing strains were less susceptible to gentamicin and had a 12-fold increase in MICs. We found similar resistance results for amikacin, gentamicin, and netilmicin, and the $a d e B$ overexpression in this resistant isolates was found to be 21.38-51.68 fold higher than that in the susceptible isolates. Lari et al. ${ }^{[21]}$ suggested that the efflux-based system AdeABC was an important contributor to reduced susceptibility to antibiotics of choice for treatment, including ciprofloxacin and cefepime, in the A. baumannii isolates.

Ardebili et al. ${ }^{[22]}$ reported that p.His158Leu, p.Pro116Ser, p.Val120lle, and p.Ala136Val were the most common aminoacid changes in the AdeR regions, whereas the p.Lys84Glu, p.Ala97Ser, and p.Gly103Asp were the most common aminoacid changes in the AdeS regions. They also reported that these changes had caused increased ciprofloxacin MICs, similar with aminoglycosides. We also found similar results for these mutations in ciprofloxacin. Richmond et al. ${ }^{[23]}$ reported that the strains in p.Ala94Val mutation in the AdeS region were observed to have 91-fold higher ade $B$ expression than the non-mutagenic strains. Similarly, several studies have shown the same results ${ }^{[24-26]}$. 
Table 2. Aminoacid substitutions in the ade $R$ and adeS genes of 34 aminoglycoside-resistant isolates in the displayed levels of ade $B$ overexpression

\begin{tabular}{|c|c|c|c|}
\hline No. of isolates & $\begin{array}{l}\text { Levels of ade } B \\
\text { gene expression }\end{array}$ & $\begin{array}{l}\text { Changes in the ade } R \text { aminoacid } \\
\text { sequence }\end{array}$ & Changes in the adeS aminoacid sequence \\
\hline 2 & 44.54 & p.Val120Ile, p.Leu142Ile, p.His158Leu & p.Lys84Glu, p.Gly103Asp \\
\hline 3 & 48.65 & p.Pro116Ser, p.Ala136Val & p.Ala97Ser, p.Gly103Asp, p.Gly293Ser \\
\hline 5 & 41.23 & p.Val120lle, p.Leu142lle & p.Ala94Val, p.His227Asp \\
\hline 9 & 49.54 & p.Val120lle & p.Gly103Asp, p.Val279Ala \\
\hline 10 & 39.43 & p.Leu142Ile, p.His158Leu & p.Val186Gly, p.Val279Ala \\
\hline 13 & 48.37 & p.Pro116Ser, p.Ala136Val & p.Ala97Ser, p.His227Asp, p.Val279Ala, p.Gly293Ser \\
\hline 19 & 51.68 & p.Pro116Ser, p.Val120lle & p.Leu105Phe, p.His227Asp \\
\hline 20 & 48.25 & p.Pro116Ser, p.Ala136Val, p.Lys84Glu & p.Ala97Ser, p.Val279Ala \\
\hline 22 & 39.54 & p.Val120lle & p.Val279Ala, p.Gly293Ser \\
\hline 23 & 39.65 & p.Pro116Ser, p.Ala136Val & p.Lys84Glu, p.Ala97Ser \\
\hline 24 & 30.43 & p.Gly36Val, p.Pro116Ser & p.Leu105Phe \\
\hline 25 & 33.59 & p.Gly36Val, p.Pro116Ser & p.Asp60Tyr, p.Val279Ala \\
\hline 26 & 48.24 & p.Val120lle, p.Leu142Ile & p.Ala97Ser, p.Gly103Asp \\
\hline 27 & 41.39 & p.Val120lle, p.Leu142Ile & p.Ala94Val, p.Gly293Ser \\
\hline 28 & 40.13 & p.Gly36Val, p.Pro116Ser & p.Gly103Asp, p.Gly293Ser \\
\hline 29 & 32.35 & p.Pro116Ser & p.Val59lle, p.Ala94Val \\
\hline 30 & 32.42 & p.Val120lle, p.Leu142Ile, p.His158Leu & p.Ala94Val, p.His227Asp \\
\hline 31 & 38.251 & p.Met88Leu, p.His158Leu & p.Val186Gly \\
\hline 32 & 38.69 & p.His158Leu & p.Lys84Glu, p.Gly293Ser \\
\hline 33 & 31.16 & p.Val120lle, p.Leu142lle & p.Asp60Tyr, p.His227Asp \\
\hline 34 & 21.38 & p.Ala136Val & p.Leu105Phe, p.Gly293Ser \\
\hline 35 & 39.15 & p.Val120lle, p.Leu142Ile & p.Leu105Phe, p.Gly293Ser \\
\hline 36 & 41.58 & p.Val120lle, p.Ala136Val & p.Gly103Asp, p.Gly293Ser \\
\hline 37 & 32.83 & p.Val120lle, p.Leu142Ile & p.Lys84Glu, p.Gly293Ser \\
\hline 38 & 39.59 & p.Met88Leu, p.His158Leu & p.Lys84Glu, p.Val245lle \\
\hline 39 & 42.09 & p.Val120lle, p.Ala136Val & p.Ala97Ser, p.Gly293Ser \\
\hline 50 & 51.03 & p.Pro116Ser, p.His158Leu & p.Ala94Val \\
\hline 51 & 51.03 & p.Pro116Ser, p.His158Leu & p.Ala94Val \\
\hline 52 & 48.75 & p.Pro116Ser & p.Asp60Tyr, p.Val245lle \\
\hline 55 & 38.54 & p.Pro116Ser & p.His227Asp, p.Val245Ile \\
\hline 57 & 49.56 & p.Pro116Ser, p.His158Leu & p.Ala97Ser, p.Gly293Ser \\
\hline 58 & 41.26 & p.Val120lle, p.Leu142Ile & p.Ala94Val, p.Val245lle, p.Gly293Ser \\
\hline 59 & 42.39 & p.Pro116Ser & p.Val59lle \\
\hline 61 & 36.45 & p.Met88Leu, p.His158Leu & p.Val186Gly \\
\hline
\end{tabular}

To the best of our knowledge, this is the first study in our country to detect both mutations in AdeRS and the expression level in ade $B$ on the clinical $A$. baumannii isolates.

\section{Conclusion}

These results demonstrated that AdeABC efflux pump overexpression (both $a d e B$ expression and AdeRS mutation) is higher than expected in our A. baumannii isolates. They were significantly associated with the AdeABC efflux system and both CRAB and MDR isolates. The overexpression of $a d e B$ and aminoacid changes in the AdeRS regions lead to an increase in resistance to different antibiotics. Nosocomial A. baumannii strains especially the MDR strains should be monitored to ensure correct treatment. 
Table 3. Aminoacid substitutions in the ade $R$ and ade $S$ genes of 49 carbapenem-resistant $A$. baumannii isolates in the displayed levels of adeB overexpression

\begin{tabular}{|c|c|c|c|}
\hline No. of isolates & $\begin{array}{l}\text { Levels of ade } B \text { gene } \\
\text { expression }\end{array}$ & $\begin{array}{l}\text { Changes in the ade } R \text { aminoacid } \\
\text { sequence }\end{array}$ & Changes in the adeS aminoacid sequence \\
\hline 1 & 36.85 & p.Val120lle, p.His158Leu & p.Lys84Glu, p.Ala97Ser, p.Val279Ala \\
\hline 2 & 44.54 & p.Val120lle, p.Leu142Ile, p.His158Leu & p.Lys84Glu, p.Gly103Asp \\
\hline 5 & 41.23 & p.Val120lle, p.Leu142Ile & p.Ala94Val, p.His227Asp \\
\hline 7 & 3.45 & p.Val120lle, p.Leu142lle & p.Leu105Phe, p.Gly293Ser \\
\hline 10 & 39.43 & p.Leu142Ile, p.His158Leu & p.Val186Gly, p.Val279Ala \\
\hline 12 & 51.15 & p.Val120lle, p.Leu142lle & p.Leu105Phe, p.His227Asp, p.Gly293Ser \\
\hline 13 & 48.37 & p.Pro116Ser, p.Ala136Val & p.Ala97Ser, p.His227Asp, p.Val279Ala, p.Gly293Ser \\
\hline 14 & 7.65 & p.Val120lle, p.Leu142lle & p.Leu105Phe, p.Val279Ala \\
\hline 15 & 10.35 & p.Val120lle, p.Ala136Val & p.Val186Gly, p.His227Asp, p.Val279Ala \\
\hline 23 & 39.65 & p.Pro116Ser, p.Ala136Val & p.Val59lle, p.Ala94Val \\
\hline 24 & 30.43 & p.Gly36Val, p.Pro116Ser & p.Leu105Phe \\
\hline 25 & 33.59 & p.Gly36Val, p.Pro116Ser & p.Asp60Tyr, p.Val279Ala \\
\hline 26 & 48.24 & p.Val120lle, p.Leu142Ile & p.Ala97Ser, p.Gly103Asp \\
\hline 27 & 41.39 & p.Val120lle, p.Leu142lle & p.Ala94Val, p.Gly293Ser \\
\hline 28 & 40.13 & p.Gly36Val, p.Pro116Ser & p.Gly103Asp, p.Gly293Ser \\
\hline 29 & 32.35 & p.Pro116Ser & p.Val59lle, p.Ala94Val \\
\hline 30 & 32.42 & p.Val120Ile, p.Leu142Ile, p.His158Leu & p.Ala94Val, p.His227Asp \\
\hline 31 & 38.251 & p.Met88Leu, p.His158Leu & p.Val186Gly \\
\hline 32 & 38.69 & p.His158Leu & p.Lys84Glu, p.Gly293Ser \\
\hline 41 & 52.18 & p.Val120lle, p.His158Leu & p.Gly103Asp, p.Gly293Ser \\
\hline 42 & 49.14 & p.Val120lle, p.Leu142Ile, p.His158Leu & p.His227Asp, p.Gly293Ser \\
\hline 44 & 35.49 & p.Met88Leu, p.His158Leu & p.Gly293Ser \\
\hline 46 & 39.56 & p.Met88Leu, p.His158Leu & p.Gly293Ser \\
\hline 47 & 43.81 & p.Pro116Ser & p.Ala94Val, p.Gly293Ser \\
\hline 48 & 8.36 & p.His158Leu & p.Val59lle, p.Gly293Ser \\
\hline 49 & 9.43 & p.His158Leu & p.Val59lle, p.Val245Ile \\
\hline 50 & 51.03 & p.Pro116Ser, p.His158Leu & p.Ala94Val \\
\hline 51 & 51.03 & p.Pro116Ser, p.His158Leu & p.Ala94Val \\
\hline 52 & 48.75 & p.Pro116Ser & p.Asp60Tyr, p.Val245lle \\
\hline 55 & 38.54 & p.Pro116Ser & p.His227Asp, p.Val245lle \\
\hline 56 & 35.78 & p.His158Leu & p.Val245Ile, p.Gly293Ser \\
\hline 57 & 49.56 & p.Pro116Ser, p.His158Leu & p.Ala97Ser, p.Gly293Ser \\
\hline 58 & 41.26 & p.Val120lle, p.Leu142lle & p.Ala94Val, p.Val245Ile, p.Gly293Ser \\
\hline 59 & 42.39 & p.Pro116Ser & p.Val59lle \\
\hline 60 & 44.12 & p.Pro116Ser & p.Val59lle, p.Ala94Val, p.Val245Ile \\
\hline 61 & 36.45 & p.Met88Leu, p.His158Leu & p.Val186Gly \\
\hline
\end{tabular}




\section{Ethics}

Ethics Committee Approval: The study approved by the Clinical Research Ethics Committee of İstanbul University-Cerrahpaşa, Cerrahpaşa Faculty of Medicine (decision no: 2015/147).

Informed Consent: The written informed consent was obtained from the study participants.

Peer-review: Externally and internally peer-reviewed.

\section{Authorship Contributions}

Concept: O.A., H.A., M.D., F.K.Ç., Design: O.A., H.A., M.D., F.K.Ç., Data Collection or Processing: O.A., H.A., M.D., Analysis or Interpretation: M.D., F.K.Ç., Literature Search: O.A., M.D., F.K.Ç., Writing: O.A., M.D., F.K.Ç.

Conflict of Interest: No conflict of interest was declared by the authors.

Financial Disclosure: The authors declared that the study was funded by the Scientific Research Projects Coordination Unit of İstanbul University-Cerrahpaşa (project number: 41923/3547).

\section{References}

1. Nowak J, Seifert H, Higgins PG. Prevalence of eight resistance-nodulationdivision efflux pump genes in epidemiologically characterized Acinetobacter baumannii of worldwide origin. J Med Microbiol. 2015;64:630-5.

2. Zhang $T$, Wang $M$, Xie $Y$, Li X, Dong Z, Liu $Y$, Wang L, Yang $M$, Song $H$, Cao $\mathrm{H}$, Cao W. Active efflux pump adeB is involved in multidrug resistance of Acinetobacter baumannii induced by antibacterial agents. Exp Ther Med. 2017;13:1538-46.

3. Howard A, O'Donoghue M, Feeney A, Sleator RD. Acinetobacter baumannii: An emerging opportunistic pathogen. Virulence. 2012;3:243-50.

4. Lin MF, Lin YY, Tu CC, Lan CY. Distribution of different efflux pump genes in clinical isolates of multidrug-resistant Acinetobacter baumannii and their correlation with antimicrobial resistance. J Microbiol Immunol Infect. 2017;50:224-31.

5. Wieczorek P, Sacha P, Czaban S, Hauschild T, Ojdana D, Kowalczuk O, Milewski R, Poniatowski B, Niklinski J, Tryniszewska E. Distribution of AdeABC efflux system genes in genotypically diverse strains of clinical Acinetobacter baumannii. Diagn Microbiol Infect Dis. 2013;77:106-9.

6. Xing L, Barnie PA, Su Z, Xu H. Development of Efflux Pumps and Inhibitors (EPIs) in A. baumannii. Clin Microbial. 2014;3:135.

7. Jia W, Li C, Zhang H, Li G, Liu X, Wei J. Prevalence of Genes of OXA-23 Carbapenemase and AdeABC Efflux Pump Associated with Multidrug Resistance of Acinetobacter baumannii Isolates in the ICU of a Comprehensive Hospital of Northwestern China. Int J Environ Res Public Health. 2015;12:10079-92.

8. Jassim KA, Ghaima KK, Saadedin SMK. AdeABC Efflux Pump Genes in Multidrug Resistant Acinetobacter baumannii Isolates. Avicenna J Clin Microb Infect. 2016;3:40898.

9. Peleg AY, Adams J, Paterson DL. Tigecycline Efflux as a Mechanism for Nonsusceptibility in Acinetobacter baumannii. Antimicrob Agents Chemother. 2007;51:2065-9.

10. European Committee on Antimicrobial Susceptibility Testing (EUCAST). Last Accessed date: 01.06.2020. Available from: https://eucast.org/
11. Livak KJ, Schmittgen TD. Analysis of relative gene expression data using real-time quantitative PCR and the 2(-Delta Delta $\mathrm{C}(\mathrm{T})$ ) Method. Methods. 2001;25:402-8.

12. Selasi GN, Nicholas $A$, Jeon $H_{1}$ Na SH, Kwon HI, Kim YJ, Heo ST, Oh MH, Lee JC. Differences in Biofilm Mass, Expression of Biofilm-Associated Genes, and Resistance to Desiccation between Epidemic and Sporadic Clones of Carbapenem-Resistant Acinetobacter baumannii Sequence Type 191. PLoS One. 2016;11:0162576.

13. Bratu S, Landman D, Martin DA, Georgescu C, Quale J. Correlation of Antimicrobial Resistance with Beta-Lactamases, the OmpA-Like Porin, and Efflux Pumps in Clinical Isolates of Acinetobacter baumannii Endemic to New York City. Antimicrob Agents Chemother. 2008;52:2999-3005.

14. Yoon EJ, Courvalin P, Grillot-Courvalin C. RND-Type Efflux Pumps in Multidrug-Resistant Clinical Isolates of Acinetobacter baumannii: Major Role for AdeABC Overexpression and AdeRS Mutations. Antimicrob Agents Chemother. 2013;57:2989-95.

15. Coyne $S$, Courvalin P, Périchon B. Efflux-Mediated Antibiotic Resistance in Acinetobacter spp. Antimicrob Agents Chemother. 2011;55:947-53.

16. Pagdepanichkit S, Tribuddharat C, Chuanchuen R. Distribution and expression of the Ade multidrug efflux systems in Acinetobacter baumannii clinical isolates. Can J Microbiol. 2016;62:794-801.

17. Sun JR, Perng CL, Chan MC, Morita Y, Lin JC, Su CM, Wang WY, Chang TY, Chiueh TS. A Truncated AdeS Kinase Protein Generated by ISAba1 Insertion Correlates with Tigecycline Resistance in Acinetobacter baumannii. PLoS ONE. 2017;7:49534.

18. Li XZ, Nikaido H. Efflux-mediated drug resistance in bacteria: an update. Drugs. 2009;69:1555-623.

19. Qiu ZQ, Zhu U, Hou PF. Distribution of carbapenemases and efflux pump in carbopenems-resistance Acinetobacter baumannii. Peer J Preprints. 2016;4:2655.

20. Coyne S, Guigon G, Courvalin P, Périchon B. Screening and Quantification of the Expression of Antibiotic Resistance Genes in Acinetobacter baumannii with a Microarray. Antimicrob Agents Chemother. 2010;54:333-40.

21. Lari AR, Ardebili A, Hashemi A. AdeR-AdeS mutations \& overexpression of the AdeABC efflux system in ciprofloxacin-resistant Acinetobacter baumannii clinical isolates. Indian J Med Res. 2018;147:413-21.

22. Ardebili A, Lari AR, Talebi M. Correlation of Ciprofloxacin Resistance with the AdeABC Efflux System in Acinetobacter baumannii Clinical Isolates. Ann Lab Med. 2014;34:433-8.

23. Richmond GE, Evans LP, Anderson MJ, Wand ME, Bonney LC, Ivens A, Chua KL, Webber MA, Sutton JM, Peterson ML, Piddock U. The Acinetobacter baumannii Two-Component System AdeRS Regulates Genes Required for Multidrug Efflux, Biofilm Formation, and Virulence in a Strain-Specific Manner. mBio. 2016;7:430-16.

24. Higgins $P G$, Schneiders $T$, Hamprecht $A$, Seifert H. In Vivo Selection of a Missense Mutation in adeR and Conversion of the Novel blaOXA-164 Gene into blaOXA-58 in Carbapenem-Resistant Acinetobacter baumannii Isolates from a Hospitalized Patient. Antimicrob Agents Chemother. 2010;54:5021-7.

25. Sun JR, Chan MC, Chang TY, Wang WY, Chiueh TS. Overexpression of the adeB Gene in Clinical Isolates of Tigecycline-Nonsusceptible Acinetobacter baumannii without Insertion Mutations in adeRS. Antimicrob Agents Chemother. 2010;54:4934-8.

26. Wieczorek $P$, Sacha $P$, Czaban $S$, Hauschild $T$, Ojdana $D$, Kowalczuk 0 , Milewski R, Poniatowski B, Niklinski J, Tryniszewska E. Distribution of AdeABC efflux system genes in genotypically diverse strains of clinical Acinetobacter baumannii. Diagn Microbiol Infect Dis. 2013;77:106-9. 
Supplementary Table 1. Genbank accesion number

\begin{tabular}{|c|c|c|c|c|c|c|}
\hline & Number & abal & AdeB & AdeR & AdeS & Genbank Accession No \\
\hline 1 & 90 & 0,379 & 0,179 & - & - & GU647217.1 \\
\hline 2 & 104 & 0,104 & 0,175 & - & - & GU647217.1 \\
\hline 3 & 154 & 0,269 & 0,306 & - & p.Val186Gly & GU647217.1 \\
\hline 4 & 178 & 0,302 & 0,591 & - & p.Val245Ile, p.Gly293Ser & GU647216.1 \\
\hline 5 & 252 & 0,315 & 0,643 & - & p.Val245Ile & GU647217.1 \\
\hline 6 & 275 & 0,158 & 0,615 & p.Gly36Val & p.Val245lle & GU647217.1 \\
\hline 7 & 301 & 0,105 & 0,783 & p.Gly36Val & p.Asp60Tyr, p.Val245Ile & GU647217.1 \\
\hline 8 & 309 & 0,468 & 0,593 & p.Gly36Val & - & GU647217.1 \\
\hline 9 & 321 & 0,259 & 0,653 & - & p.Val186Gly, p.Val245lle & GU647217.1 \\
\hline 10 & 325 & 0,198 & 0,485 & p.Ala136Val & - & GU647217.1 \\
\hline 11 & 598 & 0,169 & 0,690 & - & p.Val186Gly & GU647217.1 \\
\hline 12 & 1242 & 0,196 & 0,259 & - & - & GU647217.1 \\
\hline 13 & 1399 & 0,233 & 0,364 & - & p.Val186Gly, p.Val245lle & GU647217.1 \\
\hline 14 & 1475 & 0,109 & 0,109 & - & - & GU647217.1 \\
\hline 15 & 1611 & 0,391 & 0,264 & - & p.Asp60Tyr, p.Val245lle & GU647217.1 \\
\hline 16 & 1798 & 1,608 & 21,380 & p.Ala136Val & p.Leu105Phe, p.Gly293Ser & KF147860.1 \\
\hline 17 & 2641 & 0,194 & 0,109 & - & p.Asp60Tyr, p.Val245lle & KF147860.1 \\
\hline 18 & 3269 & 1,351 & 49,140 & p.Val120lle, p.Leu142Ile, p.His158Leu & p.His227Asp, p.Gly293Ser & KF147860.1 \\
\hline 19 & 3410 & 0,952 & 40,130 & p.Gly36Val, p.Pro116Ser & p.Gly103Asp, p.Gly293Ser & GU647217.1 \\
\hline 20 & 3415 & 0,176 & 0,331 & - & p.Asp60Tyr, p.Val279Ala & GU647217.1 \\
\hline 21 & 5034 & 0,115 & 0,245 & - & - & HM440348.1 \\
\hline 22 & 5140 & 0,257 & 0,391 & - & - & GU647217.1 \\
\hline 23 & 5544 & 1,739 & 39,150 & - & - & GU647217.1 \\
\hline 24 & 5888 & 1,526 & 43,810 & p.Pro116Ser & p.Ala94Val, p.Gly293Ser & GU647217.1 \\
\hline 25 & 6039 & 0,301 & 0,652 & p.Gly36Val & - & GU647217.1 \\
\hline 26 & 6534 & 1,115 & 8,360 & - & p.Val59lle, p.Gly293Ser & GU647217.1 \\
\hline 27 & 8039 & 1,609 & 41,580 & p.Val120Ile, p.Ala136Val & p.Gly103Asp, p.Gly293Ser & KF147860.1 \\
\hline 28 & 8179 & 1,350 & 32,830 & p.Val120lle, p.Leu142Ile & p.Lys84Glu, p.Gly293Ser & KF147860.1 \\
\hline 29 & 9226 & 0,875 & 42,090 & p.Val120lle, p.Ala136Val & p.Ala97Ser, p.Gly293Ser & KF147860.1 \\
\hline 30 & 9289 & 1,756 & 52,180 & p.Val120lle, p.His158Leu & p.Gly103Asp, p.Gly293Ser & KF147860.1 \\
\hline 31 & 9476 & 1,424 & 39,590 & p.Met88Leu, p.His158Leu, & p.Lys84Glu, p.Val245lle & KF147860.1 \\
\hline 32 & 11067 & 0,357 & 0,357 & - & p.Val279Ala & KF147860.1 \\
\hline 33 & 14911 & 0,109 & 0,482 & - & p.Asp60Tyr, p.Val186Gly & GU647217.1 \\
\hline 34 & 16791 & 1,322 & 0,430 & - & - & GU647217.1 \\
\hline 35 & 21122 & 0,736 & 39,650 & p.Pro116Ser, p.Ala136Val & - & GU647217.1 \\
\hline 36 & 25035 & 0,865 & 39,540 & p.Val120lle & p.Val279Ala, p.Gly293Ser & GU647217.1 \\
\hline 37 & 25037 & 0,209 & 0,713 & - & p.Val245Ile & GU647217.1 \\
\hline 38 & 25683 & 1,699 & 32,420 & p.Val120lle, p.Leu142Ile, p.His158Leu & p.Ala94Val, p.His227Asp & GU647217.1 \\
\hline 39 & 25790 & 1,753 & 48,240 & p.Val120lle, p.Leu142Ile & p.Ala97Ser, p.Gly103Asp & GU647217.1 \\
\hline 40 & 25936 & 0,642 & 41,390 & p.Val120lle, p.Leu142lle & p.Ala94Val, p.Gly293Ser & GU647217.1 \\
\hline 41 & 26911 & 0,814 & 0,310 & - & - & KF147860.1 \\
\hline 42 & 27443 & 1,304 & 30,430 & p.Gly36Val, p.Pro116Ser & p.Leu105Phe & GU647217.1 \\
\hline 43 & 28453 & 1,103 & 33,590 & p.Gly36Val, p.Pro116Ser & p.Asp60Tyr, p.Val279Ala & GU647217.1 \\
\hline 44 & 28825 & 0,379 & 0,639 & - & p.Val279Ala & KF147860.1 \\
\hline 45 & 29532 & 1,819 & 35,490 & p.Met88Leu, p.His158Leu, & p.Gly293Ser & EU290753.1 \\
\hline 46 & 29696 & 0,979 & 32,350 & p.Pro116Ser & - & KF147860.1 \\
\hline 47 & 30171 & 0,912 & 0,430 & - & - & KF147860.1 \\
\hline 48 & 31014 & 0,350 & 0,374 & - & p.Val279Ala & GU647217.1 \\
\hline 49 & 32485 & 1,531 & 38,690 & p.His158Leu & p.Lys84Glu, p.Gly293Ser & GU647217.1 \\
\hline 50 & 32556 & 0,209 & 0,324 & - & p.Val245Ile & GU647217.1 \\
\hline 51 & 33285 & 0,316 & 0,119 & - & p.Val245Ile & GU647217.1 \\
\hline 52 & 33679 & 0,301 & 0,301 & - & p.Val245Ile, p.Gly293Ser & GU647217.1 \\
\hline
\end{tabular}




\begin{tabular}{|c|c|c|c|c|c|c|}
\hline 53 & 34988 & 0,424 & 0,168 & - & p.Val245Ile, p.Val279Ala & EU290753.1 \\
\hline 54 & 35100 & 0,189 & 0,217 & - & - & EU290753.1 \\
\hline 55 & 35204 & 0,184 & 0,358 & - & p.Asp60Tyr, p.Gly293Ser & KF147860.1 \\
\hline 56 & 35204 & 0,304 & 0,403 & - & - & GU647217.1 \\
\hline 57 & 35329 & 0,206 & 0,248 & - & p.Val186Gly, p.Gly293Ser & KF147860.1 \\
\hline 58 & 36745 & 0,136 & 0,376 & - & p.Val245lle & KF147860.1 \\
\hline 59 & 37929 & 0,406 & 0,677 & p.Ala136Val & p.Val245Ile & GU647217.1 \\
\hline 60 & 38640 & 1,690 & 31,160 & p.Val120lle, p.Leu142lle & p.Asp60Tyr, p.His227Asp & GU647217.1 \\
\hline 61 & 42501 & 1,084 & 39,560 & - & - & GU647217.1 \\
\hline 62 & 46718 & 0,351 & 0,351 & - & - & GU647217.1 \\
\hline 63 & 552118 & 1,562 & 51,680 & p.Pro116Ser, p.Val120lle & p.Leu105Phe, p.His227Asp & KF147860.1 \\
\hline 64 & 5123284 & 1,901 & 0,401 & - & - & GU647217.1 \\
\hline 65 & 5136889 & 1,539 & 10,350 & p.Val120lle, p.Ala136Val & $\begin{array}{l}\text { p.Val186Gly, p.His227Asp, } \\
\text { p.Val279Ala }\end{array}$ & GU647217.1 \\
\hline 66 & 5137368 & 1,453 & 44,540 & p.Val120lle, p.Leu142Ile, p.His158Leu & p.Lys84Glu, p.Gly103Asp & GU647217.1 \\
\hline 67 & 5137630 & 1,696 & 7,650 & - & p.Leu105Phe, p.Val279Ala & KF147860.1 \\
\hline 68 & 5151414 & 1,542 & 41,490 & p.Pro116Ser, p.Ala136Val & p.Lys84Glu, p.Ala94Val & GU647217.1 \\
\hline 69 & 5173984 & 1,119 & 48,250 & p.Pro116Ser, p.Ala136Val & $\begin{array}{l}\text { p.Lys84Glu, p.Ala97Ser, } \\
\text { p.Val279Ala }\end{array}$ & GU647217.1 \\
\hline 70 & 5177284 & 1,634 & 48,650 & p.Pro116Ser, p.Ala136Val & $\begin{array}{l}\text { p.Ala97Ser, p.Gly103Asp, } \\
\text { p.Gly293Ser }\end{array}$ & GU647217.1 \\
\hline 71 & 5178320 & 1,195 & 51,150 & p.Val120lle, p.Leu142lle & $\begin{array}{l}\text { p.Leu 105Phe, p.His227Asp, } \\
\text { p.Gly293Ser }\end{array}$ & GU647217.1 \\
\hline 72 & 5187267 & 1,113 & 49,540 & p.Val120lle & p.Gly103Asp, p.Val279Ala & KF147860.1 \\
\hline 73 & 5287358 & 0,987 & 0,540 & - & - & GU647217.1 \\
\hline 74 & 5290338 & 1,432 & 0,230 & - & - & GU647217.1 \\
\hline 75 & 5310874 & 1,824 & 3,450 & - & p.Leu105Phe, p.Gly293Ser & KF147860.1 \\
\hline 76 & 5375595 & 0,743 & 0,370 & - & - & GU647217.1 \\
\hline 77 & 5469297 & 1,853 & 36,850 & p.Val120lle, p.His158Leu & $\begin{array}{l}\text { p.Lys84Glu, p.Ala97Ser, } \\
\text { p.Val279Ala }\end{array}$ & GU647217.1 \\
\hline 78 & 5506625 & 1,317 & 41,230 & p.Val120lle, p.Leu142Ile & p.Ala94Val, p.His227Asp & GU647217.1 \\
\hline 79 & 5596058 & 1,395 & 0,491 & - & - & GU647217.1 \\
\hline 80 & 5601323 & 1,091 & 0,540 & - & - & GU647217.1 \\
\hline 81 & 5624172 & 1,712 & 0,390 & - & - & GU647217.1 \\
\hline 82 & 5643804 & 1,175 & 39,430 & p.Leu142Ile, p.His158Leu & p.Val186Gly, p.Val279Ala & GU647217.1 \\
\hline 83 & 5713144 & 1,845 & 48,370 & p.Pro116Ser, p.Ala136Val & $\begin{array}{l}\text { p.Ala97Ser, p.His227Asp, } \\
\text { p.Val279Ala, p.Gly293Ser }\end{array}$ & GU647217.1 \\
\hline 84 & 5970545 & 1,574 & 38,540 & p.Pro116Ser & p.His227Asp, p.Val245Ile & GU647217.1 \\
\hline 85 & 5983935 & 1,648 & 35,780 & p.His158Leu & p.Val245Ile, p.Gly293Ser & GU647217.1 \\
\hline 86 & 5984229 & 0,988 & 0,510 & - & - & GU647217.1 \\
\hline 87 & 6026977 & 1,391 & 42,390 & p.Pro116Ser & p.Val59lle & GU647217.1 \\
\hline 88 & 6098203 & 0,858 & 0,480 & - & - & GU647217.1 \\
\hline 89 & 6112218 & 1,658 & 48,750 & p.Pro116Ser & p.Asp60Tyr, p.Val245lle & GU647217.1 \\
\hline 90 & 6162108 & 1,209 & 41,260 & p.Val120lle, p.Leu142lle & $\begin{array}{l}\text { p.Ala94Val, p.Val245lle, } \\
\text { p.Gly293Ser }\end{array}$ & GU647217.1 \\
\hline 91 & 6235443 & 1,150 & 36,890 & - & p.Leu105Phe, p.Val245lle & GU647217.1 \\
\hline 92 & 6306281 & 1,766 & 9,430 & p.His158Leu & p.Val59lle, p.Val245Ile & GU647217.1 \\
\hline 93 & 6309830 & 1,109 & 49,560 & p.Pro116Ser, p.His158Leu & p.Ala97Ser, p.Gly293Ser & GU647217.1 \\
\hline 94 & 6430344 & 1,310 & 51,030 & p.Pro116Ser, p.His158Leu & p.Ala94Val & GU647217.1 \\
\hline 95 & 6451132 & 1,694 & 44,120 & p.Pro116Ser & $\begin{array}{l}\text { p.Val59lle, p.Ala94Val, } \\
\text { p.Val245Ile }\end{array}$ & GU647217.1 \\
\hline 96 & 28684 & 1,817 & 38,251 & p.Met88Leu, p.His158Leu, & p.Val186Gly & GU647217.1 \\
\hline 97 & 28685 & 1,767 & 36,450 & p.Met88Leu, p.His158Leu, & p.Val186Gly & GU647217.1 \\
\hline 98 & ATCC19606 & 1,000 & 1,000 & & & GU647217.1 \\
\hline
\end{tabular}

